\title{
ガソリン浸漬下における疲労試験装置および高強度鋼の疲労特性
}

\author{
笠牟田 悠貴* 渡邊 将貴* 杉本 大気* 木村 友哉* 小川 文男** \\ 各務 周*** 宮本 宣幸 $* * * *$ 伊藤 隆基 $* * * * *$
}

\section{Fatigue Testing Equipment and Fatigue Property of a High Strength Steel in Petrol Environment}

by

\author{
Yuuki Kasamuta*, Masaki Watanabe*, Taiki Sugimoto*, Yuuya Kimura*, Fumio Ogawa**, \\ Shu Kagami ${ }^{* * *}$, Nobuyuki Miүamoto**** and Takamoto Iтон ${ }^{* * * * *}$
}

It has been known that material strength used in corrosive environment will be lowered compared with structural materials used in air due to the effect of corrosion fatigue. However, there are few research data concerning fatigue tests under petrol environment assuming actual usage. In this study, fatigue tests on a type of 440C stainless steel, which has been used as a part of the automobile fuel injection system, under air and petrol environment were conducted by means of a small sized specimen and a small sized fatigue testing machine performable in corrosion and flammable liquid. The testing machine can be also used for fatigue tests under push-pull loading at high frequency region. In addition, the fracture surface was observed by SEM and EDS to confirm the difference of fracture morphology in air and corrosive environment. Additional fatigue tests were also conducted in order to investigate the mechanism of corrosion fatigue. Fatigue lives in air were on the same level as those in regular petrol while fatigue lives in deteriorated petrol focusing on corrosion were dramatically decreased due to the difference of fracture origin.

\section{Key words:}

440C stainless steel, Fatigue, Corrosion, Petrol, Fatigue testing, Fatigue life

\section{1 緒言}

腐食環境下で使用される構造材料は，腐食の影響を受 けることで破断繰返し数が著しく低下し，大気中で用い られる構造材料と比較して早期に疲労破壊が生じる腐食 疲労が問題となっている ${ }^{1), 2)}$. その中でも, 近年の自動車 業界においては，環境意識の高まりや石油燃料の不安定 な価格変動に対応するために, 自動車の排ガス低減・燃費 向上が求められている.この対策の一つとして, 燃料噴射 圧の上昇が挙げられ，自動車用エンジン内の燃料噴射装 置が受ける疲労負荷はますます厳しくなる傾向にある. また, 自動車に使用されるガソリン燃料は, エタノールや メタノール等の添加物による多様化 3), 4) や, 国や地域等 の品質の差 5), 6) による粗悪化が進行しており，腐食環境 下においては，より過酷な条件での使用 7) 9) が余儀なく されている。したがって, 実機を想定した腐食環境下にお ける材料強度評価を実施するためには, 自動車用構造材 料としての使用環境を模擬したガソリン浸漬下における 疲労試験を実施し，腐食の影響を考慮したより信頼性の 高い疲労強度特性の把握が必要である.しかし, ガソリン
燃料は揮発性が高く極めて引火しやすいため, ガソリン 浸漬下における疲労試験は非常に危険であり, 同環境下 における腐食疲労試験結果はこれまで十分に報告されて いない.

本研究では安全面を十分に考慮してガソリン浸漬下に おける疲労試験が実施可能な小型腐食疲労試験装置を示 すとともに，同試験装置を用いて自動車用燃料噴射装置 で使用されるマルテンサイト系ステンレス鋼の大気中お よび腐食環境下における疲労試験を実施した。 また, 破断 した試験片の破面観察を行い, 腐食による破断繰返し数 の強度低下の要因について考察した.

\section{2 腐食疲労試験装置}

\section{$2 \cdot 1$ 試験装置概要}

本研究で用いた試験装置を Fig. 1 に示す. 使用した疲労 試験装置は，本研究室で独自に開発したコンピュータ制 御による電気油圧サーボ式小型腐食疲労試験装置である. 本試験装置中央部には, 密閉性が確保された環境槽を備 え付けることにより, ガソリン中における疲労試験を可

\footnotetext{
$\dagger$ 原稿受理 令和3年 1月 9日 Received Jan. 9, $2021 \quad$ C2021 The Society of Materials Science, Japan

* 立命館大学大学院理工学研究科 $\overline{7} 525-8577$ 草津市野路東

Graduate School of Ritsumeikan University, Nojihigashi, Kusatsu 525-8577

** 正会員 東北大学大学院工学研究科 厂980-8579 仙台市青葉区荒巻字青葉

Graduate School of Engineering, Tohoku University, Aoba-ku, Sendaii 980-8579

***（株)デンソー $\bar{\top} 448-8661 \quad$ 刈谷市昭和町

Diesel Injection Engineering Division, DENSO CORPORATION, Showa-cho, Kariya 448-8661

**** 正会員 (株)デンソー †448-8661 刈谷市昭和町

Materials Engineering R\&D Division, DENSO CORPORATION, Showa-cho, Kariya 448-8661

***** 正会員 立命館大学理工学部機械工学科 $\bar{\top} 525-8577$ 草津市野路東

Department of Mechanical Engineering, Ritsumeikan University, Nojihigashi, Kusatsu 525-8577
} 
能とした.また，試験片の脱着は環境槽前後の蓋を取り外 して行い，試験実施中はその蓋の中央部に設けられてい るガラス空から疲労試験の様子を観察することができる. 試験装置本体が小型であることから，設置スペースの縮 小および製作コストの削減，ならびに小型試験片を用い ての疲労試験を実現した。また, 試験時間の短縮化のため にロッド部分を中空にして慣性力を減らすことにより， $100 \mathrm{~Hz}$ までの高い試験周波数域での疲労試験を可能とし た。ロードセルは装置の最下部に設置し，最大荷重は $\pm 10 \mathrm{kN}$ である。

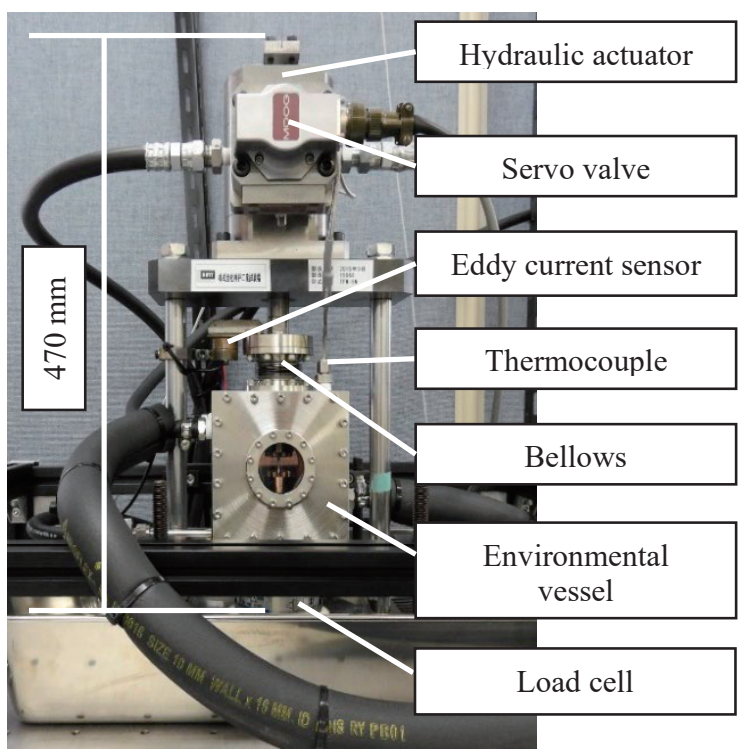

Fig. 1 Miniature fatigue testing machine (470H 230W 230D, Unit: mm).

\section{$2 \cdot 2$ ガソリン燃料循環および冷却システム}

実機を想定したガソリン浸漬下において疲労試験を安 全に行うために, 試験装置には Fig. 2 に示すガソリン燃料 循環装置および冷却水循環装置が備え付けられている. 冷却水循環装置の仕様を Table 1 に示す.

ガソリン浸漬下における疲労試験では，ガソリン燃料 の化学成分や温度の偏りが生じてしまうことが懸念され るため, 試験環境においてガソリン燃料の状態および試 験温度を統一寸る必要がある. また, 試験装置内でガソリ ン燃料を長時間用いることにより，ガソリン燃料の試験 温度が上昇して火災等の危険性が考えられるため，試験 温度も制御する必要がある。したがって, 安全かつ正確な 腐食疲労データの取得を行うためには，ガソリン燃料の 攪挥，ならびに試験環境の均一性を保つ装置が必要であ る.そこで本試験装置には, 試験装置および外部にそれぞ れ試験環境槽および循環水冷却槽を設置し，各槽間でガ ソリン燃料を循環させることにより，化学成分や温度の 偏りを防ぐ仕組となっている. また, 循環水冷却槽内に冷 却コイルを導入し，コイル内に冷却水を循環させること でガソリン燃料温度の均一化を実現し, 安全面も考慮し たガソリン浸漬下における疲労試験を可能とした.
本試験装置では，揮発性の高いガソリン燃料を用いる ため, 試験装置の気密性を保つ必要がある. そこで, 油圧 アクチュエータおよび環境槽間に高気密性のベローズを 採用し，室内に気化したガソリン燃料が外に漏れないよ うにした。一方で, 環境槽および冷却槽内を大気圧に保つ ために，環境槽および冷却槽から屋外にかけて通気管を 伸ばして開放している.

Table 1 Specification of circulation and cooling system.

\begin{tabular}{c|c}
\hline Cooling method & Circulating water \\
\hline Temperature control & PID control \\
\hline Water-temperature & $8{ }^{\circ} \mathrm{C} \sim$ Room temp. \\
\hline Volume of environment vessel & $500 \mathrm{~m} l$ \\
\hline Volume of cooling vessel & $2000 \mathrm{~m} l$ \\
\hline
\end{tabular}

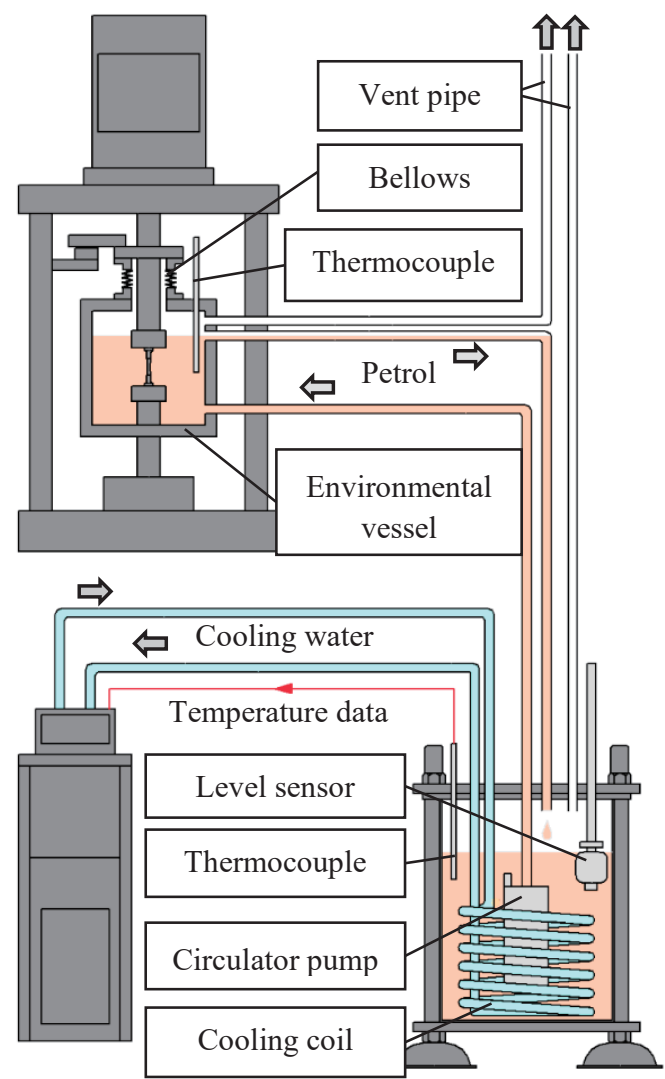

Cooling water

Cooling vessel circulation apparatus

Fig. 2 Overview of liquid circulation and cooling systems.

\section{$3 \cdot 1$ 試験片}

\section{3 試験条件}

本研究で用いた供試材は, 特殊な熱処理を施すことに より他系統のステンレス鋼よりも高硬度であるが，耐食 性は若干劣るマルテンサイト系の 440C 系ステンレス鋼

（以下，440 SS と呼ぶ）および440 SS をベースに耐食性 を向上させたステンレス鋼（以下， I-440 SS と呼ぶ）であ 
Table 2 Average values of hardness and residual stress.

\begin{tabular}{c|c|c}
\hline Material & $\begin{array}{c}\text { Vickers hardness } \\
\text { HV }\end{array}$ & $\begin{array}{c}\text { Residual stress } \\
\sigma_{\mathrm{R}}, \mathrm{MPa}\end{array}$ \\
\hline $440 \mathrm{SS}$ & 709 & -136 \\
\hline $\mathrm{I}-440 \mathrm{SS}$ & 657 & -545 \\
\hline
\end{tabular}

る. $440 \mathrm{SS}$ の試験片の形状および寸法を Fig. 3 に示す. 本

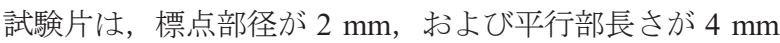
の中実丸棒試験片である. なお, I-440 SS の試験片形状は, 素材の丸棒直径の大きさが限られていたため，ボタンへ ッド部の径を $6.4 \mathrm{~mm}$ としたが，その他の形状は Fig. 3 と 同様である。

440 SS および I-440 SS 共に，素材から一次加工の後に 熱処理を行い，最終的に仕上げ加工および以下の条件で 表面研磨を行っている.440 SS は\#600 および\#800で円周 方向に素研磨を行い，\#320で軸方向に仕上げ研磨を行っ ている.アルミナ研磨剤で仕上げを行い, 表面の平均粗さ は Ra 0.07 である. I-440 SS については\#320，\#600および \#800 で円周方向に素研磨を行い，\#800 で軸方向に仕上げ 研磨を行っている．最終的にアルミナ研磨剤で仕上げを 行い, 表面の平均粗さは Ra 0.06 である.また両材料共に, 仕上げ後の観察により目視できるき裂や窪みがないこと を確認している.

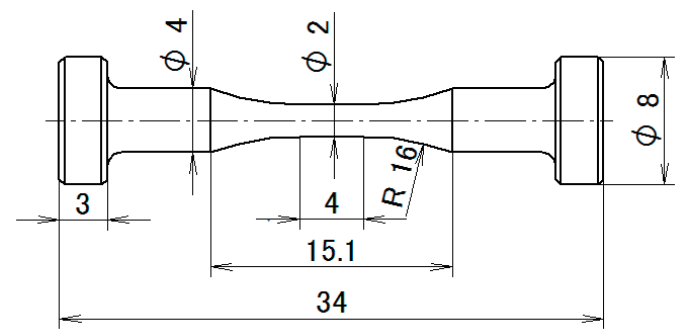

Fig. 3 Shape and dimensions of specimen for $440 \mathrm{SS}(\mathrm{mm})$.

各供試材の硬度および表面残留応力を測定した結果を Table 2 に示す. 硬度は，マイクロビッカース硬さ試験機 $(2.94 \mathrm{~N}, 15 \mathrm{sec})$ を用いて試験部断面を 11 点測定し，そ れらの平均值とした. 残留応力は, $\mathrm{X}$ 線回折装置を用いて 試験部中央の表面を，440 SS で 2 本，I-440 SS で 3 本の試 験片に対して測定し，それぞれの平均值とした。硬度は $440 \mathrm{SS}$ の方が $50 \mathrm{HV}$ 程度高いが大差は無い。一方, 残留 応力は, I-440 SS の方が圧縮側の残留応力が高くなってい る. 残留応力の発生原因については, 材料作製時の温度分 布および組織の不均一性，表面加工の影響が考えられる. $440 \mathrm{SS}$ と I-440 SS で残留応力值が大きく異なるが， I-440 SS では炭素，クロム，モリブデンが添加されており，こ れらの元素の相互作用の影響で高い残留応力が発生して いると推察される. 後述するが, 研磨により試験片表面の 残留応力層を除去すると疲労寿命が短くなることから， 残留応力は試験片表面に局所的に存在すると考えられる. 残留応力はある定の厚みを持って表面に分布しており,
この厚みの中で残留応力の正負が均衡していると考えら れる. 表面は圧縮側であり, ある程度の厚さを越えると引 張に遷移すると考えると，後述するような表面き裂と内 部き裂の合体による破壊様式も合理的に説明出来る.

\section{$3 \cdot 2$ 試験条件}

440 SS では，試験環境を大気中，市販のガソリン（以 下，ガソリンと呼ぶ）中およびメタノール含有ガソリン中 とし，引張・圧縮負荷下における疲労試験を実施した。こ こで，メタノール含有ガソリンとは， $1 l$ 中にメタノール $15 \%$ およ゙水, 酢酸, 硫黄, 塩化ナトリウムを添加して劣 化ガソリンを再現したものであり, 以下では M15 と呼ぶ. なお，I-440 SS については，大気中およびM15 中のみ疲 労試験を実施した. 大気中の疲労試験については, 環境槽 の蓋を閉じずに実施した。環境槽内のガソリン燃料温度 は, $10 \pm 1{ }^{\circ} \mathrm{C}$ で制御し, 応力比 $R=\sigma_{\min } / \sigma_{\max }=-1\left(\sigma_{\min }\right.$ : 最小応力, $\sigma_{\text {max }}$ : 最大応力）の両振り荷重にて, 軸荷重制 御で実施した.また, 疲労試験では揮発性の高いガソリン 燃料を用いるため, 試験周波数は試験片が温度上昇しな い $f=20 \mathrm{~Hz}$ とした．なお，破断繰返し数 $N_{\mathrm{f}}$ は，試験片が 破断するまでの繰返し数と定義した.

試験後の試験片に対して走査型電子顕微鏡（Scanning Electron Microscope : SEM），エネルギー分散型 X 線分光 器（Energy Dispersive X-ray Spectroscopy : EDS）および電 解放出型電子線マイクロアナライザ (FE-EPMA) を用い て破面観察を実施し，破壊様相に及ぼす各試験環境の影 響について考察した。また，M15 中における疲労試験結 果に着目し，腐食影響による強度低下の原因を調べるた めの追加試験も実施した。

\section{4 試験結果および考察}

\section{$4 \cdot 1$ 各試験環境下における疲労試験結果}

各試験条件における応力振幅 $\sigma_{\mathrm{a}}$ と破断繰返し数 $N_{\mathrm{f}}$ との 関係を Fig. 4 に示す．ただし，Fig. 4 中の右向き矢印を付 しているデータは，疲労試験中に試験片が破断しなかっ たために, 試験を中断したときの繰返し数である. なお,

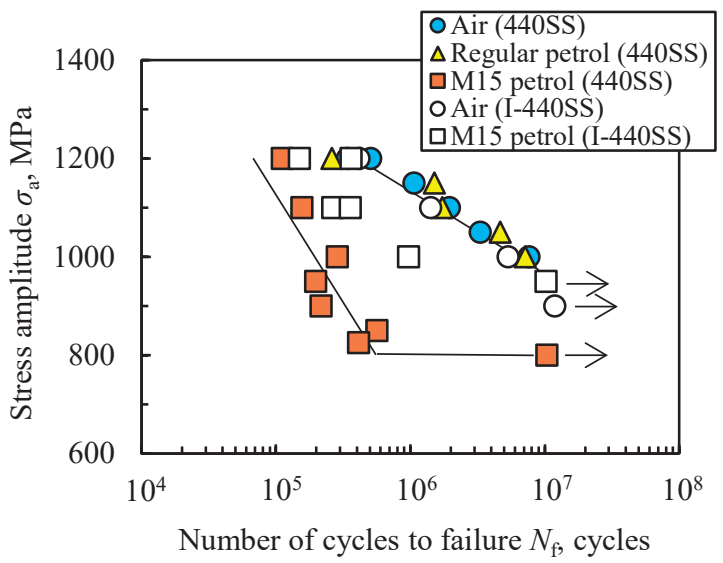

Fig. 4 S-N diagram under air and petrol environment. 


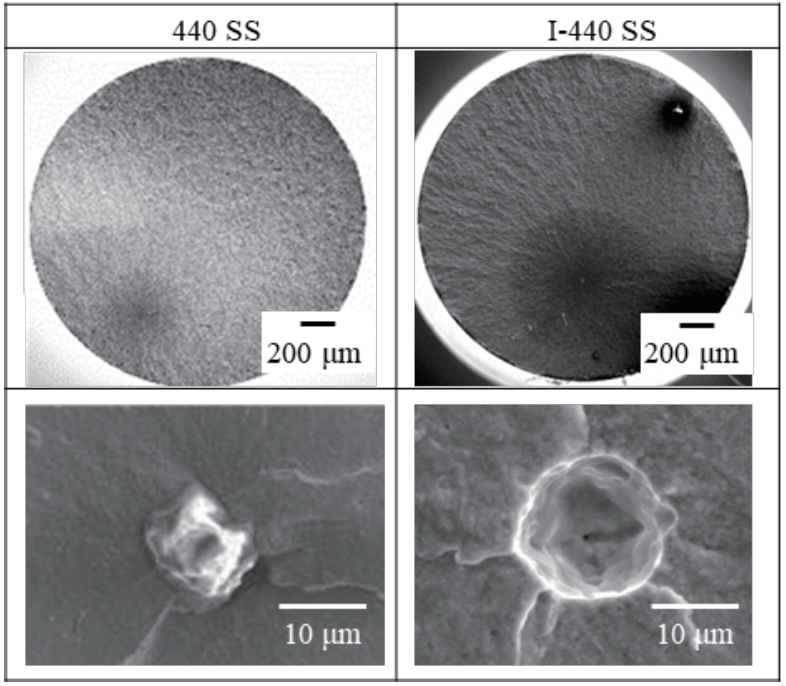

(a) In air

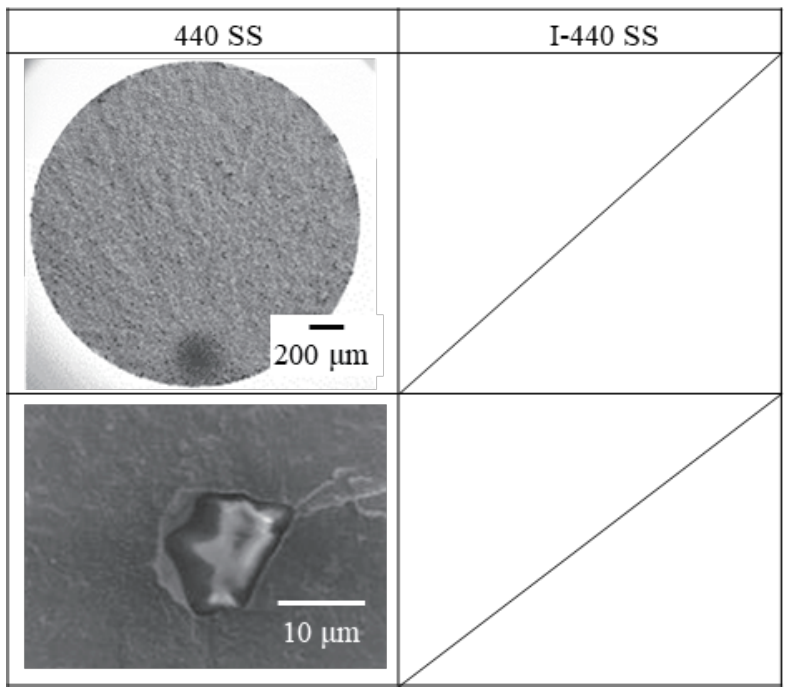

(b) In regular petrol

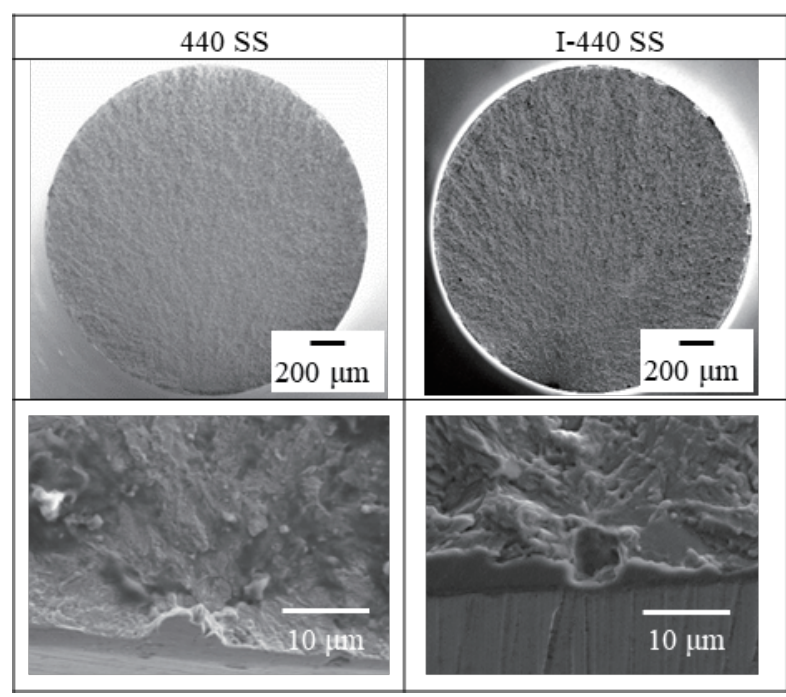

(c) In M15

Fig. 5 Observations of fracture surface at $\sigma_{\mathrm{a}}=1100 \mathrm{MPa}$.

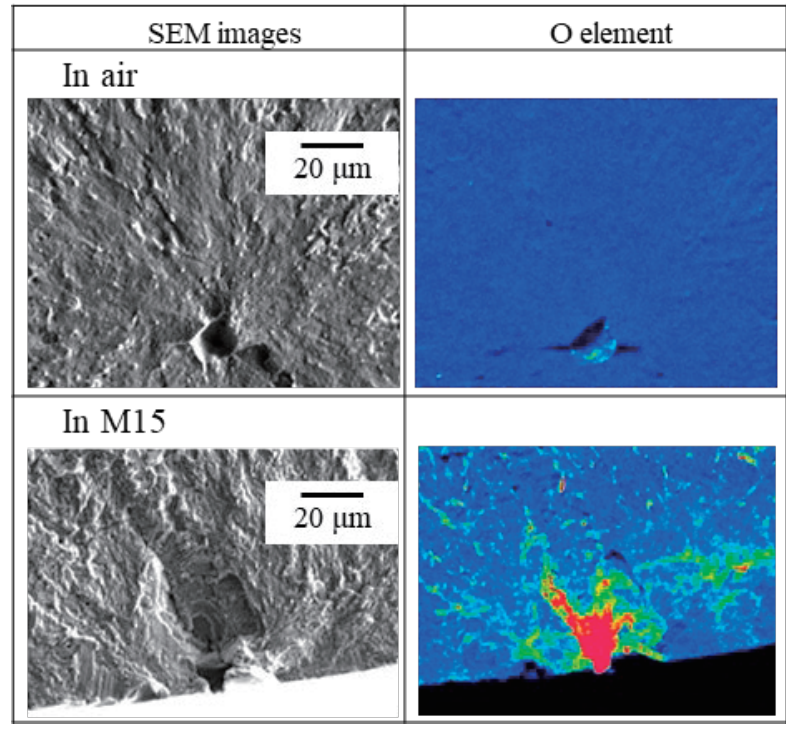

Fig. 6 FE-EPMA results of fracture-initiating points.

本研究では, 繰返し数が $N=10^{7}$ cycles に達したときに未 破断の場合は試験を中断した.

440 SS を用いた大気中およびガソリン中における疲労 試験では，応力振幅によらず破断繰返し数がほぼ同等で あるが, M15 中における疲労試験では, 各試験条件と比 較して著しく破断繰返し数が低下し，その低下度合いは 低応力振幅域ほど寿命差が大きくなることが確認された. また, M15 中の応力振幅 $\sigma_{\mathrm{a}}=800 \mathrm{MPa}$ では, $N=10^{7}$ cycles にて未破断であった.

I-440 SS を用いた疲労試験では, 大気中と比較して M15 中の破断繰返し数が低下したが，その寿命低下の度合い は440 SS と比較して小さいことが確認された。ささに， 440 SS および I-440 SS の破断繰返し数を比較すると, 大 気中における疲労試験では差異はほとんど見られない。

一方で, M15 中における疲労試験では，I-440 SS の破断繰 返し数は増加していることが確認された。これについて, 両材料の表面残留応力層を研磨により $30 \mu \mathrm{m}$ ほど除去した試 験片を用いて追加試験を実施した. その結果, 破断繰返し数が 減少することおよび440SS と I-440SS で減少の度合いが同程 度となることが確認された. 残留応力は試験片表面にある程 度の厚みを持って分布しており, その中で正負の均衡が取れ ていることから, 残留応力層の圧縮側一M15 に含まれる腐食 成分が作用することでこの均衡が破れ, 内部き裂の発生, 成 長, 表面き裂との合体が起こり, 強度低下が引き起こされたと 考えられる.

\section{$4 \cdot 2$ 破面観察}

440 SS および I-440 SS の各試験条件における破面観察 結果を Fig. 5 (a)〜 (c)に示す. また, 440 SS の大気中およ び M15 中の試験片については, FE-EPMA を用いた破壊 起点部における酸素の分析結果を Fig. 6 に, 各試験条件に おける破壊起点部の EDS 分析結果を Fig. 7 に示す.なお, 破面は $\sigma_{\mathrm{a}}=1100 \mathrm{MPa}$ における試験後のものである. 


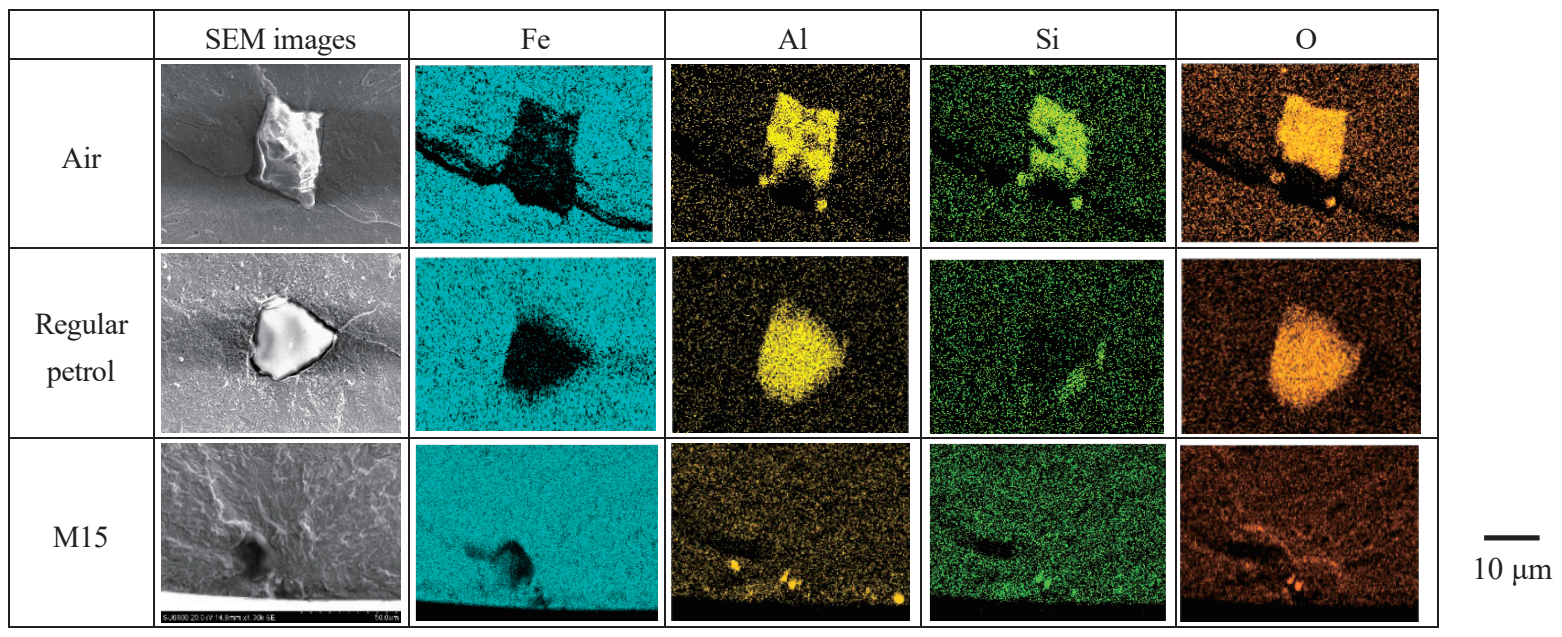

Fig. 7 Element analysis of fracture-starting points.

Fig. 5 (a)および(b)より，大気中およびガソリン中におけ る疲労試験では，材料や応力振幅に関わらずすべての試 験片破面においてフィッシュアイ 7) 13) が観察され，その 中心部には介在物（または脱落痕）が見られた. EDS を用 いて起点部を分析した結果 $\mathrm{Al}$ や $\mathrm{Si}$ の存在が確認された

（Fig. 7）ことから，起点に見られた介在物は酸化物系で あると推定される. 以上より, 大気中およびガソリン中に おける疲労試験では, 介在物を起点とした内部起点型疲 労破壊であった. 残留応力值に差がある両材料において, 大気中での破断繰返し数が同等となる原因としては，残 留応力が試験片表面に局所的に存在することで内部起点 型の疲労破壊には影響を及ぼさないためであると考えら れる。

一方, Fig. 5 (c)の M15 中における疲労試験では, 両材 料共にフィッシュアイは観察されず，試験片表面付近を 起点とする疲労破壊であり, 起点部には介在物および腐 食を伴った領域が認められた. Fig. 6 に示すように, M15 中における破面の起点部では酸素が検出されていること より，腐食の影響を受けて表面付近を起点とする疲労破 壊が発生したことが示唆される.また, 疲労試験結果で低 応力域ほど S-N 曲線の差が大きくなる現象については, 試験片表面付近の粒界における比較的軟化している部分

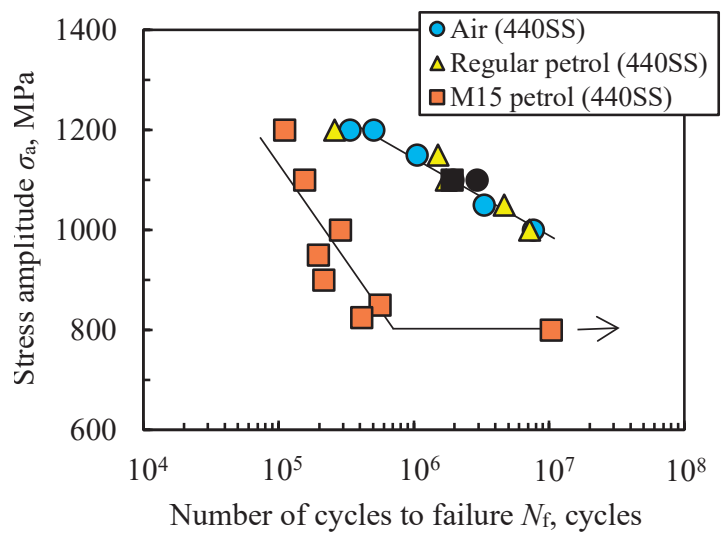

Fig. 8 S-N diagram with additional test under immersion in M15 for 440 SS.
でき裂が生じ，そのまま表面へと進展することが原因で あると考えられる。これについては前述の残留応力の均 衡の変化と関係あると考えられるが, 詳細は今後の検討 課題とする.

\section{5 腐食による強度低下の影響因子検討}

\section{$5 \cdot 1$ 腐食環境下における負荷の影響}

上述したように，M15 中における疲労試験では，腐食 の影響により結果的に大気中およびガソリン中における 内部起点型とは異なる表面付近を起点とする疲労破壊に 至ったことが示唆された．本章では，M15 中で腐食によ る疲労寿命低下が生じる影響因子について，440 SS を用 いた追加試験から検討する.

試験片を M15 中に無負荷状態で $32 \mathrm{~h}\left(2.0 \times 10^{6}\right.$ cycles 相 当）浸漬させた後, 大気中における疲労試験を実施した. なお, M15 浸漬中において化学成分や濃度に偏りを生じ させないため, 疲労試験機の環境槽内にて, 無負荷で浸漬 した. 大気中の疲労試験条件は, これまでと同条件となる 試験周波数 $f=20 \mathrm{~Hz}$, 応力比 $R=-1$ の軸荷重制御であり, 応力振幅 $\sigma_{\mathrm{a}}=1100 \mathrm{MPa}$ とした. 試験結果を Fig. 4 の S-N 線図中に追加プロットし, Fig. 8 に示寸 (Fig. 8 中○（黒 塗丸）プロット).

Fig. 8 から, 本試験結果は M15 中に浸漬させたことに 関係無く, 大気中およびガソリン中と同等の破断繰返し 数が得られたことが確認できる. Fig. 9 (a) (c)に疲労試験 後の試験片 $\left(\sigma_{\mathrm{a}}=1100 \mathrm{MPa}\right)$ に対して, SEM およびEDS による破面観察を実施した結果を示す，同図(a)および(b) より，大気中およびガソリン中における疲労試験結果と 同様にフィッシュアイが認められ, 内部起点型疲労破壊 であることが確認された. 同図(c)より, 介在物にあたる部 分には $\mathrm{O}$ や $\mathrm{Al}$ が検出されていることから, $\mathrm{Al}_{2} \mathrm{O}_{3}$ 等を主 成分とした介在物であると推定される。したがって, M15 中に無負荷状態で浸漬させた場合は腐食の影響が小さい, もしくは腐食の影響がほとんど無いと考えられる.すな わち, 繰返し負荷状態ではステンレス鋼表面に生成され 


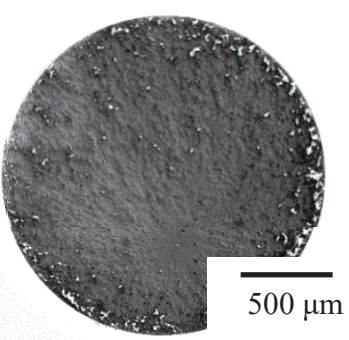

(a) Fracture surface

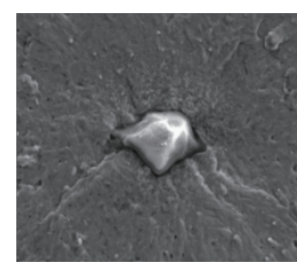

(b) Fracture origin
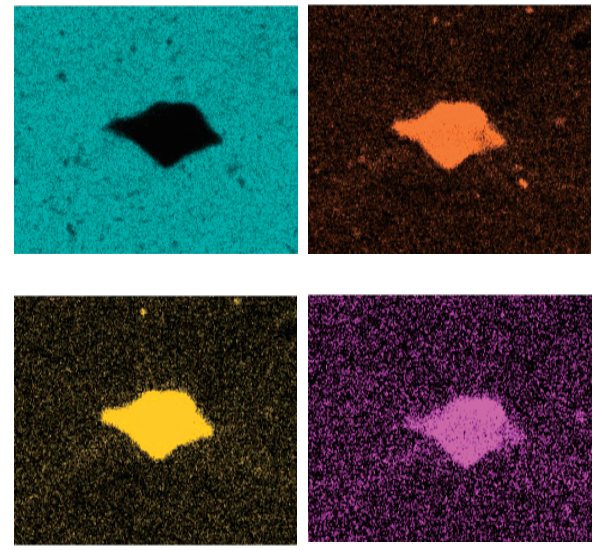

EDS

$25 \mu \mathrm{m}$

(c) EDS result

Fig. 9 Fracture surface of specimen tested immersion and M15.

る不働態被膜が破壊されその部分から腐食が進行するこ とに対して, 無負荷状態（浸漬のみ）ではその破壊が起こ らないためであることが示唆される.また, M15 中に 1100 MPa の一定負荷を作用させた状態で浸漬させた場合でも, 明瞭な腐食影響やき裂がほとんど存在しなかったため, 破壞が繰返し負荷状態で起こることが認められる.

\section{$5 \cdot 2$ 試験環境の影響}

M15 中において試験開始から破断に至るまでの腐食 過程および破断メカニズムを検討するため，440 SS に対 して試験環境を途中まで M15 中で行い, その後大気中 に変更する中断試験を実施した。

M15 中の応力振幅 $\sigma_{\mathrm{a}}=1100 \mathrm{MPa}$ で破断した疲労試験 での破断繰返し数 155984 cycles を $N_{\mathrm{f}}$ とし, 同試験条件で $0.4 N_{\mathrm{f}}$ までの疲労試験を実施した後, 大気中で試験を再開 した. $0.4 N_{\mathrm{f}}$ と大気中での破断繰返し数の合計の疲労試験 結果を Fig. 8 の（黒塗四角）プロットで示す. Fig. 8 より，本追加試験での破断繰返し数は約 $N_{\mathrm{f}}=1.9 \times 10^{6}$ cycles であり，大気中およびガソリン中における疲労試 験結果および $5 \cdot 1$ 節で示した破断繰返し数とほぼ等し い結果となった。また，試験片の破壊起点は，大気中お よびガソリン中と同様に, 介在物を起点とした内部起点 型であった (図省略)。したがって, M 15 中は $0.4 N_{\mathrm{f}}$ 程度 では $440 \mathrm{SS}$ に対して腐食の影響はほとんど無いことが 示唆された。 また，腐食影響の時間的変化を調べるため の中断試験結果 $\left(\sigma_{\mathrm{a}}=1100 \mathrm{MPa}\right)$ として, $0.8 N_{\mathrm{f}}$ および $0.9 N_{\mathrm{f}}$

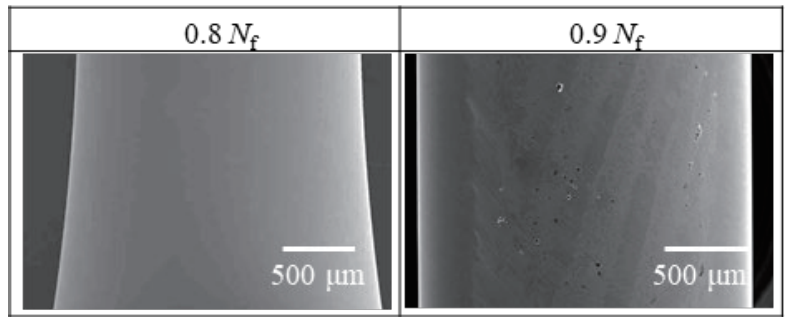

Fig. 10 The surface observation results of interruption tests.

における試験片表面は Fig. 10 に示されているように, 小 さな凹凸が確認されたもののき裂は認められなかった ため， $N_{\mathrm{f}}$ 付近でき裂が発生してすぐに破断したものと考 えられる. 今後は, 繰返し数のどの段階で腐食影響が強 くなるのか, また腐食の進行が速くなるのかを詳細に調 査する必要がある.

上記のように, ガソリン燃料中における疲労破壊のメ カニズムについて考察を行った. 本報告においては, 試 験片が破断する際の起点の効果に関しては内部起点型 と表面付近を起点とする場合とでは破壊のメカニズム が異なっており，腐食影響に対する詳細の考察が課題と して残されている，したがって今後は，切欠き等を導入 し意図的に起点を表面付近に合わせることで, 腐食疲労 のメカニズムをさらに究明する必要性があると言える.

\section{6 結 言}

440 SSおよびI-440 SSを用いて, 大気中, ガソリン中お よびM15中における疲労試験およびそれらの破面観察 を行い, 腐食の影響による疲労特性と破壊起点について 考察した.

(1) $440 \mathrm{SS}$ 用いた大気中およびガソリン中における 疲労試験では, 介在物を起点とした内部起点型疲労 破壊であった，M15中における疲労試験では，腐食 影響を受けることにより, 表面付近を起点とする疲 労破壊であった。

(2) $440 \mathrm{SS}$ おびI-440 SSの破断繰返し数を比較すると, 大気中における疲労試験では, 材料の違いによる差 異は見られなかった。一方, M15中における疲労試 験では, 両材とも大気中に対し破断繰返し数の低下 が認められたものの，440 SSに比べてI-440 SSでは 破断繰返し数は増加した.

（3）大気中およびガソリン中における内部起点型疲労 破壊は，非金属介在物である $\mathrm{Al}_{2} \mathrm{O}_{3}$ や $\mathrm{SiO}_{2}$ を起点と していると考えられる. M15中の表面付近を起点と する疲労破壊は, 起点部で酸素が多く検出されたこ とより，腐食の影響があったことが示唆された。

（4）本材料は, M15中に無負荷で浸漬させた状態では疲 労強度に及ぼす腐食の影響はなかったが, 浸漬させ た状態で繰返し負荷を与えると腐食疲労の様相が 現れた. また, $0.4 N_{\mathrm{f}}$ 程度の繰返し数では腐食の影響 による破断繰返し数の低下は認められなかった. 
試験装置の設計, 開発に関して数多くの御助言, 御協 力をいただきました(株)神戸工業試験場の高木氏, 南山 氏，秋月氏，日坂氏をはじめとする同社の皆様に厚くお 礼申し上げます。

\section{参 考 文 献}

1) T. Inoue, K. Sakaue, H. Cho and T. Ogawa, "Evaluation of stress corrosion cracking and corrosion fatigue crack growth characteristics for martensitic stainless steel", Transaction of the Japan Society of Mechanical Engineers. A, Vol.76, pp.1698-1704 (2010).

2) R. Shirasaki, H. Miyamoto and H. Fujiwara, "Formation mechanism of cracks in low-cycle corrosion fatigue of metastable austenitic stainless steel", The Harris Science Review of DOSHISHA UNIVERSITY, Vol.57, No.1, pp.1-6 (2016).

3) T. Yamada, J. Kawashima, N. Miyamoto and T. Murayama, "A study on diesel engines with alcohol fuels (Solubility and combustion characteristic with ethanol-heavy oil fuel blends)", Transactions of the Japan Society of Mechanical Engineers. B, Vol.49, pp.1087-1094 (1983).

4) T. Ueno, O. Kimura and H. Shiroyama, "Analysis on niche strategy for introduction of alternative technologies in a transportation sector", Sociotechnica, Vol.2, pp.89-99 (2004).

5) J. Jia, "A study on the state of PM2.5 issue and its measure in China", Bulletin of Sendai Shirayuri Women's College, Vol.19, pp.55-64 (2015).

6) H. Ito and K. Yokozawa, "Come! "Monozukuri” in India. Analysis of the signs of changes in Indian society and India auto expo", Akámon Management Review, Vol.15, No.8, pp.421-438 (2016).

7) K. Satoh, M. Chigasaki, T. Furuhashi, K. Terakado, Y. Nakagawa and A. Houdayer, "Corrosion failure of the valve seat surface of fuel injector operated by blend fuel of gasoline and methanol", Zairyo-to-Kankyo, Vol.43, No.3, pp.134-138 (1994).

8) T. Nozu, Y. Murakami, N. Inayoshi, K. Ooi, H. Narisako, T. Shimizu, T. Maruyama and T. Harakawa, "Development of sintered bearing material with higher corrosion resistance for fuel pumps", Denso Technical Review, Vol.12, No.2, pp.60-66 (2007).

9) O. Seri and S. Tanno, "Corrosion behavior of aluminum alloy 6063 in gasoline with ethanol”, Journal of the Japan Institute of Metals and Materials, Vol.73, No.11, pp.878-883 (2009).

10) S. Kagami, A. Ueno, N. Ishibashi, H. Honma, B. Guennec, S. Miyakawa and N. Miyamoto, "4-point bending fatigue properties of vacuum carburized SCM415 using fatigue strength evaluation method in biodiesel fuel with water", Transactions of the Society of Automotive Engineers of Japan, Vol.49, No.2, pp.484491 (2018).

11) S. Schmid, M. Hahn, S. Issler, M. Bacher-Hoechst, Y. Furuya, A. Mehner, H. Bomas and H. W. Zoch, "Effect of frequency and biofuel E85 on very high cycle fatigue behavior of the high strength steel X90CrMoV18", International Journal of Fatigue, Vol.60, pp.90-100 (2014).

12) K. Kanazawa, T. Nishimura, K. Matsuda, K. Kageyama and K. Yamaguchi, "Internal fracture with fish-eye and effect of surface improvement by dynamic strain aging on high temperature fatigue of a low alloy steel", Journal of the Society of Materials Science, Japan, Vol.52, No.6, pp.646-652 (2003).

13) Y. Furuya, S. Matsuoka, T. Kimura and M. Hayashi, "Effect of inclusion and ODA sizes on gigacycle fatigue properties of high-strength steels", Tetsu-to-Hagane, Vol.91, No.8, pp.630-638 (2005). 